\title{
Heterogeneous Mutations in the Human Lipoprotein Lipase Gene in Patients with Familial Lipoprotein Lipase Deficiency
}

\author{
Takanari Gotoda, ${ }^{*}$ Nobuhiro Yamada," Masako Kawamura, ${ }^{*}$ Koichi Kozaki," Natsuko Mori, ${ }^{\star}$ Shun Ishibashi," \\ Hitoshi Shimano," Fumimaro Takaku, ${ }^{*}$ Yoshio Yazaki, ${ }^{*}$ Yasuhiro Furuichi, ${ }^{*}$ and Toshio Murase \\ *The Third Department of Internal Medicine, Faculty of Medicine, University of Tokyo, Tokyo 113; ${ }^{\ddagger}$ Department of Molecular Genetics, \\ Nippon Roche Research Center, Kanagawa 247; and ${ }^{\S}$ Department of Endocrinology and Metabolism, \\ Toranomon Hospital, Tokyo 105, Japan
}

\begin{abstract}
The DNA sequences were determined for the lipoprotein lipase (LPL) gene from five unrelated Japanese patients with familial LPL deficiency. The results demonstrated that all five patients are homozygotes for distinct point mutations dispersed throughout the LPL gene. Patient 1 has a G-to-A transition at the first nucleotide of intron 2 , which abolishes normal splicing. Patient 2 has a nonsense mutation in exon $3\left(\mathrm{Tyr}^{61} \rightarrow\right.$ Stop) and patient 3 in exon 8 (Trp ${ }^{382} \rightarrow$ Stop). The latter mutation emphasizes the importance of the carboxy-terminal portion of the enzyme in the expression of LPL activity. Missense mutations were identified in patient 4 (Asp ${ }^{204} \rightarrow$ Glu) and patient 5 (Arg ${ }^{243}$ $\rightarrow$ His) in the strictly conserved amino acids. Expression study of both mutant genes in COS-1 cells produced inactive enzymes, establishing the functional significance of the two missense mutations. In these patients, postheparin plasma LPL mass was either virtually absent (patients 1 and 2) or significantly decreased (patients 3-5). To detect these mutations more easily, we developed a rapid diagnostic test for each mutation. We also determined the DNA haplotypes for patients and confirmed the occurrence of multiple mutations on the chromosomes with an identical haplotype. These results demonstrate that familial LPL deficiency is a heterogeneous genetic disease caused by a wide variety of gene mutations. (J. Clin. Invest. 1991. 88:1856-1864.) Key words: chylomicron • point mutation - genetic disease $\bullet$ mutagenesis • haplotype
\end{abstract}

\section{Introduction}

Lipoprotein lipase (LPL) ${ }^{1}$ plays a central role in triglyceride metabolism through catabolism of triglyceride-rich lipoprotein particles such as chylomicron and VLDL. LPL is a glycoprotein synthesized in most extrahepatic tissues and is anchored to the luminal surface of the capillary endothelium by membrane bound heparan sulfate. The action of LPL is necessary for the

Address reprint requests to Dr. Nobuhiro Yamada, The Third Department of Internal Medicine, Faculty of Medicine, University of Tokyo, Hongo 7-3-1, Tokyo 113, Japan.

Received for publication 10 December 1990 and in revised form 26 July 1991.

1. Abbreviations used in this paper: LPL, lipoprotein lipase; PCR, polymerase chain reaction; RFLP, restriction fragment length polymorphism.

J. Clin. Invest.

(c) The American Society for Clinical Investigation, Inc.

0021-9738/91/12/1856/09 \$2.00

Volume 88, December 1991, 1856-1864 supply of free fatty acids to tissues for oxidation or storage and is also an important determinant for the interconversions among lipoprotein particles (1).

A patient with a familial form of chylomicronemia was first described in 1932 (2) and LPL deficiency was noted as a cause of familial chylomicronemia in 1960 (3). Familial LPL deficiency is inherited as an autosomal recessive trait and its occurrence has been estimated to be approximately one in a million. The disease usually presents in infancy or childhood with episodic abdominal pain and abnormal appearances of lipemic plasma. The patients have severe chylomicronemia due to a defective hydrolysis of chylomicrons, a marked elevation of fasting serum triglyceride concentrations, and a drastically reduced postheparin plasma LPL activity. Other clinical features of this disease include eruptive xanthoma, lipemia retinalis, hepatosplenomegaly due to the accumulation of chylomicron fat, and recurrent attacks of pancreatitis which are often fatal (4). The heterogeneity of this disease has been suggested by the various degrees of lipolytic activity which were detected in patients upon administration of exogenous triglyceride substrate (5) and heparin infusion (6). Recent experiments using a monoclonal antibody against LPL disclosed the classification of patients into three subgroups with distinct biochemical characteristics (7).

Both the molecular cloning of LPL cDNAs $(8,9)$ and the elucidation of the human LPL gene structure (10-12) greatly facilitated genomic analysis of the patient genes. The human LPL gene has a span of $30 \mathrm{~kb}$ and comprises 10 exons that code for a 475-amino acid protein including a 27-amino acid signal peptide. Major rearrangements of the LPL gene locus were first reported in a population of Caucasian patients $(13,14)$, and recently several point mutations were also identified in American patients $(15-20)$.

In this study, we define the molecular abnormalities in the LPL gene of five Japanese patients with no familial relations. Surprisingly, all five patients were found to be homozygous for the separate gene mutations, suggesting that the genetic defects responsible for LPL deficiency are quite heterogeneous at the molecular level. Furthermore, expression studies of the mutant proteins and measurement of the LPL mass in the patient's plasma afforded a better understanding of the effect of these mutations on the enzyme molecule.

\section{Methods}

Subjects. We studied five patients and their family members from independent kindreds. A family history of consanguinity was found for each kindred. These patients were diagnosed as LPL deficient by the markedly reduced level of postheparin plasma LPL activity. LPL deficiency was recognized in three of the five patients in infancy, and had been overlooked in the other two until adulthood. One patient (patient 
1) was diagnosed at the age of $34 \mathrm{yr}$ when he had an attack of acute pancreatitis, and the other patient (patient 4) was asymptomatic but was diagnosed by chance at the age of 42 during examinations for hypertriglyceridemia. The biochemical and physical characteristics of the subjects are shown in Table I.

Southern blot analysis and haplotyping analysis. DNAs from the patients and normal subjects were isolated from peripheral white blood cells. Southern blot hybridization analysis was performed after complete digestion of $10 \mu \mathrm{g}$ of each DNA with one of the restriction enzymes, Hind III, Pst I, Pvu II, Nco I, or Bam HI (Boehringer Mannheim Biochemicals, Indianapolis, IN) as previously described (21). The 1.58-kb fragment of human LPL cDNA (22) (region 1-1,581) was used as a probe for hybridization. DNA haplotypes were constructed for the five patients using a combination of the restriction fragment length polymorphisms (RFLPs) which were identified by Hind III, Bam HI, and Pvu II $(23,24)$.

Genomic cloning and gene amplification by the polymerase chain reaction. Construction of genomic libraries was carried out with DNAs obtained from one patient (patient 1) and a normal subject as previously reported (21). By screening the libraries, four LPL gene fragments that cover exons 3-9 were obtained from each library. To obtain gene fragments containing exon 1, exon 2, and a portion of exon 10 , and to examine the DNA sequences of the LPL gene from the remaining four patients, gene amplification was performed by the polymerase chain reaction (PCR) (25). $1 \mu \mathrm{g}$ of each DNA was added to a 100- $\mu$ l reaction mixture of $50 \mathrm{mM} \mathrm{KCl}, 10 \mathrm{mM}$ Tris ( $\mathrm{pH} 8.3$ ), $1.5 \mathrm{mM} \mathrm{MgCl}_{2}, 0.01 \%$ gelatin with $0.1 \mathrm{nmol}$ of each primer, $20 \mathrm{nmol}$ of each dNTPs, and 2.5 $\mathrm{U}$ of Taq DNA polymerase (Perkin-Elmer Corp., Pomona, CA). The reaction mixture was applied to 30 cycles of PCR $\left(94^{\circ} \mathrm{C} 1 \mathrm{~min} ; 50\right.$ $55^{\circ} \mathrm{C} 2 \mathrm{~min} ; 72^{\circ} \mathrm{C} 3 \mathrm{~min}$ ), which was preceded by an additional denaturation $\left(94^{\circ} \mathrm{C} 5 \mathrm{~min}\right)$ and followed by an extension $\left(72^{\circ} \mathrm{C} 7 \mathrm{~min}\right)$. Table II shows the sequences of the oligonucleotide primers used for PCR amplification. The sequences of the four primers, which are marked with an asterisk, were derived from the published sequence of the human LPL gene (12). These sets of primers could properly amplify each of the 10 exons and the adjacent intron sequences of 10-55 bases, except for the latter portion of exon 10 which conforms to the entire 3 -untranslated region (10). Oligonucleotide primers were synthesized by the phosphoramidite method with a model 381A DNA synthesizer (Applied Biosystems, Inc., Foster City, CA).

DNA sequencing. Direct sequencing of amplified DNA was performed utilizing an unequal ratio of primers for the second PCR (26). Following the first PCR, one-hundredth of the reaction mixture was PCR amplified again as described above, together with an unequal ratio $(100: 1)$ of the same primers used in the first reaction. The singlestranded DNA from the second PCR was used for sequencing by the dideoxy method (27) with Sequenase (United States Biochemical Corp., Cleveland, $\mathrm{OH}$ ) after chloroform-extraction and filtration with a Centricon 100 microconcentrator (Amicon Corp., Danvers, MA). The cloned gene fragments and the PCR-amplified fragments containing regions with strong secondary structures were sequenced after subcloning into the $\mathrm{M} 13$ vector $\mathrm{mp} 18$ or $\mathrm{mp} 19$. All sequences were determined on both strands and the regions across a mutation were sequenced on the six independently amplified DNAs.

$R F L P$-creating PCR. To detect the mutant allele containing the splicing mutation, an artificial RFLP was created by introducing a

Table I. Characteristics of the Study Subjects

\begin{tabular}{|c|c|c|c|c|c|c|c|c|c|}
\hline \multirow[b]{2}{*}{ Subject* } & \multirow[b]{2}{*}{ Age/sex ${ }^{\ddagger}$} & \multirow[b]{2}{*}{ Triglycerides } & \multirow[b]{2}{*}{$\begin{array}{c}\text { Total } \\
\text { Cholesterol }\end{array}$} & \multirow[b]{2}{*}{$\begin{array}{l}\text { Apolipoprotein } \\
\text { C-II }\end{array}$} & \multirow[b]{2}{*}{$\begin{array}{c}\text { LPL } \\
\text { activity }\end{array}$} & \multicolumn{4}{|c|}{ Clinical manifestations } \\
\hline & & & & & & $\begin{array}{c}\text { Eruptive } \\
\text { xanthoma }\end{array}$ & $\begin{array}{l}\text { Lipemia } \\
\text { retinalis }\end{array}$ & Pancreatitis & Hepatosplenomegaly \\
\hline & & $m g / d l$ & $m g / d l$ & $m g / d l$ & $\mu m o l F F A / m l / h^{\S}$ & & & & \\
\hline P 1 & $34 / \mathbf{M}$ & 4,928 & 568 & 9.8 & 0.8 & $(-)$ & $(+)$ & $(+)$ & $(-)$ \\
\hline F 1 & $69 / \mathrm{M}$ & 112 & 204 & 3.7 & 5.4 & & & & \\
\hline S 1-1 & $38 / \mathrm{F}$ & 675 & 200 & 6.3 & 1.2 & & & & \\
\hline$S 1-2$ & $32 / \mathrm{M}$ & 89 & 203 & 4.6 & 6.2 & & & & \\
\hline C $1-1$ & $5 / \mathrm{M}$ & 102 & 185 & ND & ND & & & & \\
\hline C $1-2$ & $3 / \mathbf{M}$ & 167 & 170 & ND & ND & & & & \\
\hline P 2 & $3 \mathrm{~m} / \mathrm{F}$ & 19,120 & 824 & 11.2 & 0.9 & $(+)$ & ND & $(-)$ & $(+)$ \\
\hline F 2 & $30 / \mathbf{M}$ & 257 & 150 & 4.6 & 6.7 & & & & \\
\hline M 2 & $27 / F$ & 153 & 108 & 3.3 & 2.4 & & & & \\
\hline S 2 & $3 / F$ & 240 & 133 & 4.6 & 5.7 & & & & \\
\hline P 3 & $6 \mathrm{~m} / \mathrm{F}$ & 6,010 & 632 & 14.8 & 1.0 & $(+)$ & $(+)$ & $(-)$ & $(+)$ \\
\hline F 3 & $29 / \mathrm{M}$ & 127 & 157 & 2.9 & 6.9 & & & . & \\
\hline M 3 & $26 / F$ & 125 & 158 & 2.0 & 2.7 & & & & \\
\hline P 4 & $44 / F$ & 1,528 & 191 & 6.5 & 1.2 & $(-)$ & $(-)$ & $(-)$ & $(-)$ \\
\hline F 4 & $74 / \mathrm{M}$ & 130 & 142 & ND & 5.0 & & & & \\
\hline M 4 & $71 / \mathrm{F}$ & 173 & 230 & ND & 4.8 & & & & \\
\hline C 4-1 & $16 / \mathrm{F}$ & 137 & 179 & ND & ND & & & & \\
\hline C 4-2 & $14 / \mathrm{M}$ & 187 & 154 & ND & ND & & & & \\
\hline P 5 & $23 d / F$ & 4,794 & 560 & 6.7 & 1.1 & $(+)$ & $(+)$ & $(-)$ & $(+)$ \\
\hline F 5 & $31 / \mathrm{M}$ & 53 & 106 & 3.8 & 6.7 & & & & \\
\hline M 5 & $28 / \mathrm{F}$ & 106 & 175 & 3.6 & 3.6 & & & & \\
\hline S 5 & $3 / \mathrm{M}$ & 67 & 135 & 4.5 & 3.7 & & & & \\
\hline Normal" & & $40-150$ & $130-220$ & $3.7 \pm 1.3^{\prime}$ & $6.4 \pm 2.1^{1}$ & & & & \\
\hline
\end{tabular}

${ }^{*} \mathrm{P}, \mathrm{F}, \mathrm{M}, \mathrm{S}$, and $\mathrm{C}$ denote patient, father, mother, sibling, and child, respectively. ${ }^{\ddagger} \mathrm{m}=$ months, $\mathrm{d}=$ days. ${ }^{8} \mathrm{FFA}$, free fatty acid. " Normal values for adult subjects. 'Normal values (mean $\pm \mathrm{SD}$ ). 


\begin{tabular}{|c|c|c|c|c|c|}
\hline Exon & Sequence & 5'-Intron & $\begin{array}{c}\text { Amplified } \\
\text { exon }\end{array}$ & 3'-Intron & Total size \\
\hline & & & & $b p$ & $b p$ \\
\hline \multirow[t]{2}{*}{1} & 5'-CAAGTGACAAACAGGATTCGTC-3' * & 391 & 273 & 45 & 709 \\
\hline & 5'-ACGCCCGGGTCTGCAGGTGG-3' & & & & \\
\hline \multirow[t]{2}{*}{2} & 5'-CTCCAGTTAACCTCATATCCA-3' * & 36 & 161 & 32 & 229 \\
\hline & 5'-CAATCCACTCTTCCCCAAAGAG-3' * & & & & \\
\hline \multirow[t]{2}{*}{3} & 5'-GGTGGGTATTTTAAGAAAGCT-3' & 38 & 180 & 43 & 261 \\
\hline & 5'-AAAACACTGTTTGGACACATA-3' & & & & \\
\hline \multirow[t]{2}{*}{4} & 5'-TTGGCAGAACTGTAAGCACCT-3' & 43 & 112 & 46 & 201 \\
\hline & 5'-AGTCTTTTCACCTCTTATGATA-3' & & & & \\
\hline \multirow[t]{2}{*}{5} & 5'-ATGCGAATGTCATACGAATGG-3' & 61 & 234 & 35 & 330 \\
\hline & 5'-GAGTCACATTTAATTCGCTTC-3' & & & & \\
\hline \multirow[t]{2}{*}{6} & 5'-TCTGCCGAGATACAATCTTGG-3' & 39 & 243 & 38 & 320 \\
\hline & 5'-CTCCTTGGTTTCCTTATTTAC-3' & & & & \\
\hline \multirow[t]{2}{*}{7} & 5'-CTGAATTGCCTGACTATTTGG-3' & 76 & 121 & 40 & 237 \\
\hline & 5'-GGGACTGGTGCCATGATGAC-3' & & & & \\
\hline \multirow[t]{2}{*}{8} & 5'-GCTGTCTCTATAACTAACCCA-3' & 43 & 183 & 67 & 293 \\
\hline & 5'-ATACGGCCCCTAGGTCCTGA-3' & & & & \\
\hline \multirow[t]{2}{*}{9} & 5'-TGTTCTACATGGCATATTCAC-3' & 39 & 105 & 37 & 181 \\
\hline & 5'-TCAGGATGCCCAGTCAGCTT-3' & & & & \\
\hline \multirow[t]{2}{*}{$10^{\ddagger}$} & 5'-GAAGATAATAAATTGCCCTTT-3' * & 40 & 380 & - & 420 \\
\hline & 5'-GAATTCCAATTAAAATAGGAG-3' & & & & \\
\hline
\end{tabular}

* Sequences derived from the published data (12). ${ }^{\ddagger}$ Exon 10 encodes the entire 3 -untranslated region of $1.95 \mathrm{~kb}$.

single base mismatch into the $3^{\prime}$ portion of an oligonucleotide PCR primer. A Taq I cutting site was generated specifically in the mutant allele, using the upstream primer whose DNA sequence corresponds to the $3^{\prime}$ end of exon 2 (5'-TGGTGATCCATGGCTGGTCG-3'; the mismatched nucleotide is in italic type) and the downstream primer corresponding to $+98-+117$ of intron 2 (5'-GTAAGAGATCCACGTGAGAT-3'). The sequence of the PCR product derived from the mutant allele was thus modified to contain a new restriction site for Taq I (TCGA) across the exon 2-intron 2 boundary.

Allele-specific oligonucleotide hybridization. One-tenth of the PCR products $(10 \mu \mathrm{l})$ covering exon 3 were spotted in duplicate on nylon membrane (Hybond-N, Amersham Corp., Arlington Heights, IL). The DNA blots were hybridized with ${ }^{32} \mathrm{P}$ end-labeled synthetic oligonucleotide probes (normal, 5'-GGAATGTATGAGAGTTG-3'; mutant, 5'GGAATGTAAGAGAGTTG-3'). Both membranes were washed at $51^{\circ} \mathrm{C}$ for $15 \mathrm{~min}$ in $6 \times \mathrm{SSC}-0.1 \% \mathrm{SDS}(1 \times \mathrm{SSC}=150 \mathrm{mM} \mathrm{NaCl}, 15$ $\mathrm{mM}$ sodium citrate, $\mathrm{pH} 7.0$ ).

Site-directed mutagenesis and in vitro expression studies. To construct the normal expression plasmid (pCMV-LPL), human LPL cDNA was placed under the control of the CMV promoter. A 1,581-bp cDNA fragment (22) encompassing the entire coding sequence was cloned in the sense orientation into the Eco RI site of the Bluescript II $\mathrm{KS}+$ vector (Stratagene, La Jolla, CA). The insert was reexcised with Hind III and Xba I, and transferred to the Hind III/Xba I sites of the $\mathrm{Rc} / \mathrm{CMV}$ vector (Invitrogen, San Diego, CA). To construct the mutant expression plasmids, DNA segments containing each of the two missense mutations were generated by PCR and introduced into PCMVLPL by replacing the corresponding normal segments. For the construction of the mutant plasmid pLPL-His ${ }^{243}$, the 273-bp DNA fragment $(983-1,255)(8)$ was amplified with the mismatched 5'-primer containing the Arg $\rightarrow$ His mutation at nucleotide 983 and was introduced into the Eco 47III/Stu I sites of the partially digested pCMV-LPL plasmid. To construct the pLPL-Glu ${ }^{204}$, the 211-bp DNA fragment (783-993) comprising the Asp $\rightarrow$ Glu mutation at nucleotide 867 was created by the recombinant PCR method of Higuchi et al. (28), which utilizes two overlapping inside primers containing the same mutation in addition to the outside primers. After digestion with Acc I and Eco 47III, the resulting restricted fragment (792-982) was cloned into the partially digested pCMV-LPL. The integrity of the normal and mutant expression plasmids was verified by DNA sequencing before transfection into COS-1 cells. DNA transfections were carried out using lipofection with TransfectACE (Bethesda Research Laboratories, Gaithersburg, MD). $30 \mathrm{~h}$ after each DNA transfection, the medium was supplemented with $5 \mathrm{U} / \mathrm{ml}$ of heparin. After an additional $18 \mathrm{~h}$, the culture medium and cell extract were collected from $35-\mathrm{mm}$ dishes, flash frozen, and stored at $-70^{\circ} \mathrm{C}$.

Lipoprotein lipase activity and mass. LPL activity in plasma and culture media was determined as described previously (29), using glycerol tri $\left[1-{ }^{14} \mathrm{C}\right]$ oleate as substrate and selective blocking of the hepatic lipase activity with an antiserum to human hepatic lipase. After an overnight fast, a bolus injection of heparin $(10 \mathrm{U} / \mathrm{kg})$ was administered to each subject, and blood was collected $10 \mathrm{~min}$ after heparin injection. LPL enzyme mass was measured by a sandwich enzyme-linked immunosorbent assay (ELISA) recently developed in our laboratory (Kawamura, M., et al., unpublished data). The ELISA utilizes two separate polyclonal antibodies raised against a synthetic peptide of 16 amino acids corresponding to the $\mathrm{NH}_{2}$-terminus of the mature human LPL and against a recombinant whole human LPL. Purified human LPL was used as the standard to calculate enzyme mass. In the expression studies, the determination of LPL mass and activity were performed in octuplicates and triplicates, respectively.

\section{Results}

As shown in Table I, all five patients presented the characteristically severe hypertriglyceridemia and a reduced level of LPL activity. The possibility of the congenital absence of apolipo- 
protein C-II (30), a cofactor of LPL, could be excluded because of the increased concentration of apolipoprotein C-II observed in all five patients. One sibling (S1-1) also presented moderate hypertriglyceridemia with a markedly reduced LPL activity. Among the other family members, C1-2, F2, and S2 exhibited mild hypertriglyceridemia, as has been observed in other families of LPL-deficient patients $(15,31)$. Their fasting serum triglyceride concentrations were nearly two- to fourfold the average values of their respective age groups. In agreement with our previous results with Eco RI (21), Southern blot analysis with five other restriction enzymes showed no evidence of major rearrangement in the LPL gene locus of the patients (data not shown).

Nucleotide sequence of the entire LPL coding region and the exon-intron boundaries was determined for each patient. The results identified five distinct single-base substitutions and confirmed that no other nucleotide alterations are present in the LPL gene of the patients, except a sequence polymorphism existing 20 bases downstream from exon 3 -intron 3 junction. The A-C transversion was also found among the normal population. As expected from the family history of consanguinity, all five patients were found to be homozygous for each point mutation. Fig. 1 demonstrates the pairs of sequencing ladders that represent sequences from both normal and patient DNA containing the region near the respective mutations. Patient 1 has a G-to-A change at the first nucleotide of intron 2. This single base change disrupts the invariant GT profile of the eukaryotic 5'-donor splice site (32). Patient 2 has a T-to-A substi- tution of $\mathrm{Tyr}^{61}$ (TAT), which creates a stop codon (TAA) in exon 3 and would cause a premature termination in LPL synthesis. Another nonsense mutation was identified in the gene of patient 3 who has an A substituting for a $G$ at $\operatorname{Trp}^{382}$ (TGG), which also creates a premature termination codon (TGA) in exon 8 . Two missense mutations were found in the gene of the remaining two patients. Patient 4 has a C-to-G transversion that replaces $\mathrm{Asp}^{204}$ (GAC) with Glu (GAG) in exon 5, and patient 5 has a G-to-A transition that changes $\operatorname{Arg}^{243}$ (CGC) to His (CAC) in exon 6. To exclude the possibility of misincorporations during PCR (25), direct sequencing was performed for each patient's DNA derived from six independent amplifications by separate PCRs.

Of the five point mutations described above, three can affect the restriction sites recognized by the commercially available restriction enzymes. The point mutations in patients 3, 4, and 5 were predicted to disrupt a Mbo II site, a Hinc II site, and an Eco 47III site, respectively. Thus in these three patients, digestion of the amplified DNA with an appropriate restriction enzyme was expected to generate a distinctive fragment which is different in size from the normal ones (Fig. 2). Mbo II digestion of the PCR-amplified products of $293 \mathrm{bp}$ generated four fragments of $143,60,57$, and 33 bp for normal subjects. Instead, similar digestion of the amplified DNA from patient 3 resulted in the occurrence of the unique 203-bp fragment in addition to the common 57- and 33-bp fragments, due to the loss of one of the three internal Mbo II sites (Fig. 2, $A$ and $D$ ). Digestion of the PCR-amplified DNA containing exon 6 with
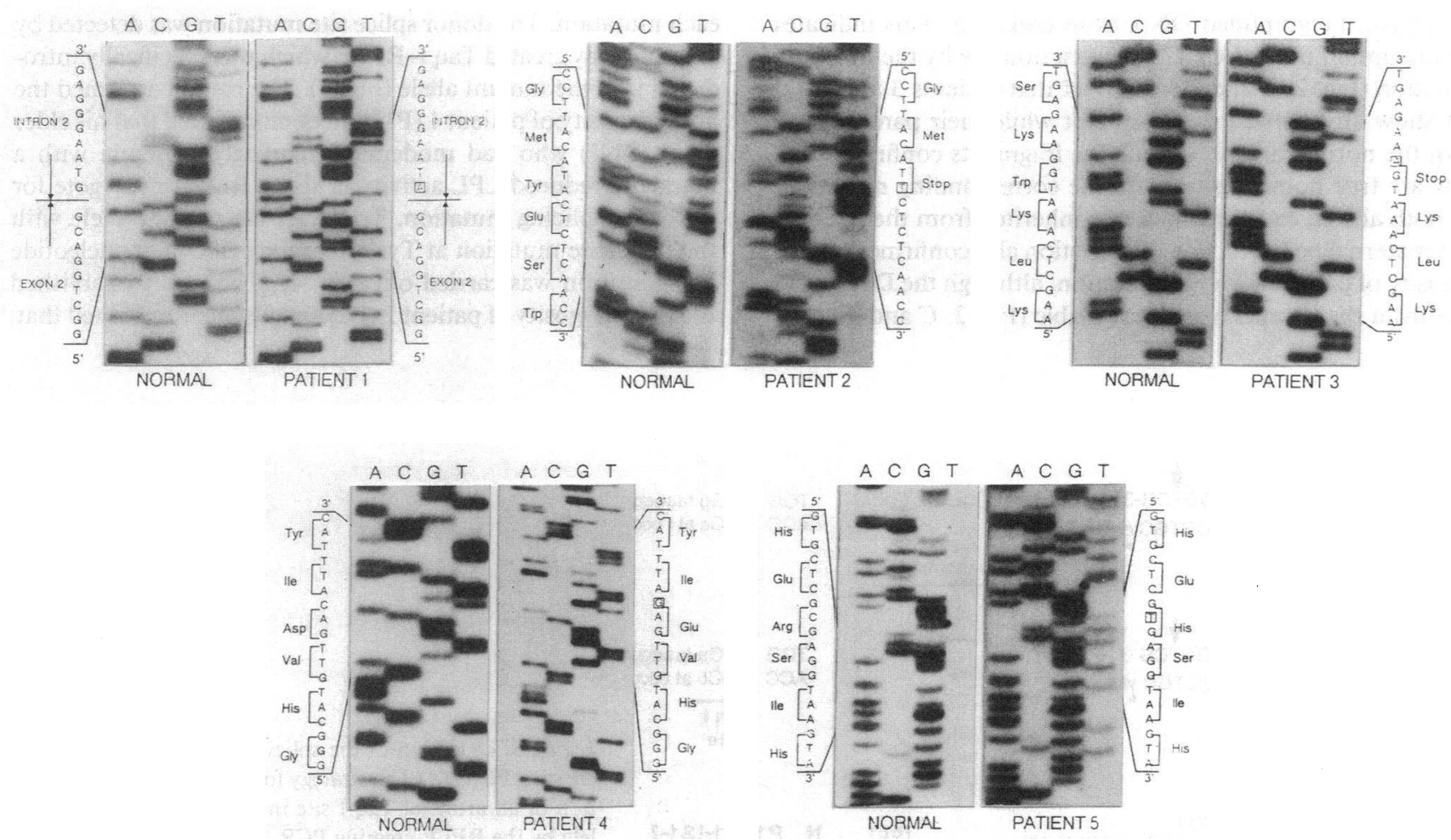

Figure 1. Comparison of DNA sequences from a normal subject and the five patients. All sequences were determined on both strands by direct sequencing of the amplified DNA, and the regions across a mutation were sequenced on the separately amplified DNAs. The sequences of the sense strand (patients $1,3,4$ ) or antisense strand (patients 2,5 ) are shown for comparison. The bases substituted in the patients are enclosed by the box. 


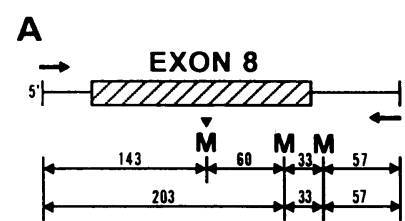

M: Mboll
B

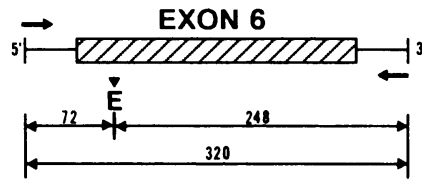

E : Eco 47III
C

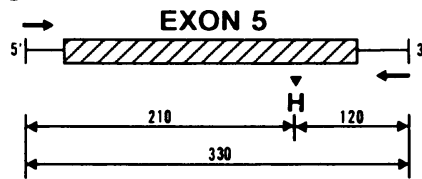

$H$ : Hinc II
E

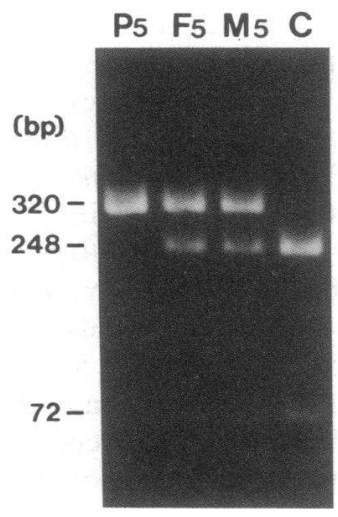

$\mathbf{F}$

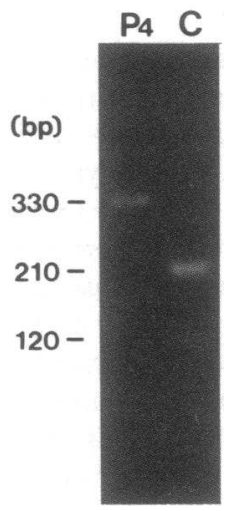

Figure 2. Detection of the three mutations by digestion with restriction enzymes. Schematic representations of the portion of the LPL gene that were amplified by the individual PCR are shown in panels $A-C$. The pairs of primers used are indicated by the arrows and the positions of normal restriction sites by the vertical lines. The restriction sites disrupted by the mutations are marked with an arrowhead. Numbers indicate the size of the fragments generated by the respective digestions. Electrophoretic analyses of the amplified DNAs from the patients (P), fathers $(F)$, mothers $(M)$, and a normal control $(C)$ were performed with $2 \%$ agarose gel after digestion of the DNAs with an appropriate restriction enzyme. As shown in panels $D-F$, the respective unique fragments were demonstrated in the DNAs from the patients, and heterozygous restriction patterns were confirmed for the parents.
Eco 47III divides the 320-bp products into two fragments of 248 and $72 \mathrm{bp}$ in normal subjects, but a similar digestion did not cleave the amplified DNA from patient 5 . This indicates the disruption of the Eco 47 III restriction site by the missense mutation (Fig. 2, $B$ and $E$ ). The fact that patients 3 and 5 did not show any normal size fragment while their parents have both the normal and abnormal size fragments confirmed that they are true homozygotes with the corresponding mutations on both alleles, each of which was inherited from the paternal and maternal pedigree. Hinc II digestion also confirmed homozygosity of patient 4 for the mutation, although the DNA samples from the parents were unavailable (Fig. 2, $C$ and $F$ ).
Because the remaining two mutations cause no change in a restriction site, we developed alternative methods to detect each mutation. The donor splice site mutation was detected by an artificially created Taq I-RFLP which was specifically introduced into the mutant allele (Fig. 3). The result confirmed the homozygosity of patient 1 (P1) and demonstrated that his elder sister (S1-1) who had moderate hypertriglyceridemia with a markedly reduced LPL activity is also a true homozygote for the same splicing mutation. To detect the mutant allele with the nonsense mutation at $\mathrm{Tyr}^{61}$, allele-specific oligonucleotide hybridization was carried out (Fig. 4). The result established the homozygosity of patient 2 (P2) and also demonstrated that,

A

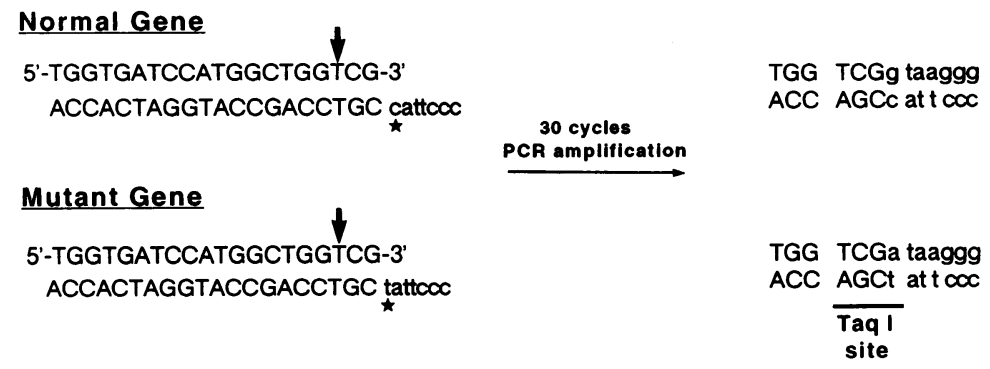

B

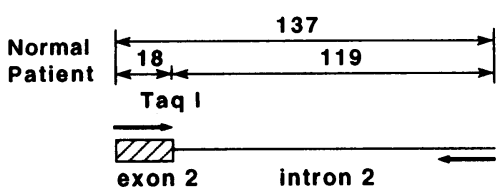

Figure 3. Detection of the splicing mutation by RFLPcreating PCR. $(A)$ The strategy for the specific introduction of an artificial Taq I site into the splicing mutant allele by the RFLP-creating PCR. (B) Taq I-digestion of the amplified DNA from the mutant allele generates the specific 119-bp fragment, as depicted in the right panel. $\mathrm{N}, \mathrm{P} 1, \mathrm{~S} 1-1$, and S1-2 denote the normal, patient 1, sister, and brother, respectively. 


\section{Normal probe : 5'- GGAATGTATGAGAGTTG -3' Mutant probe : 5'- GGAATGTAÅGAGAGTTG -3'}

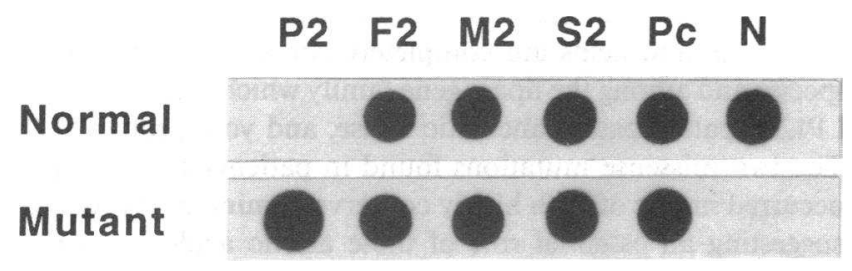

Figure 4. Detection of the nonsense mutation at $\mathrm{Tyr}^{61}$ by allele-specific oligonucleotide hybridization. The amplified genomic DNAs containing exon 3 were dot-blotted in duplicates and hybridized with two allele-specific probes for the normal and mutant sequences encompassing the nonsense mutation at $\mathrm{Tyr}^{61}$. P2, F2, M2, S2, Pc, and $\mathrm{N}$ denote the patient 2 , father 2 , mother 2 , sister 2 , compound heterozygote and normal control, respectively.

in addition to both parents (F2, M2), her elder sister (S2) as well as another LPL-deficient patient (Pc) is also heterozygous for the same mutation. Because both $\mathrm{C} 1-2$ and F2 are obligate heterozygotes, all the three family members who exhibited mild hypertriglyceridemia (C1-2, F2, and S2) are carriers for the mutations at the LPL gene locus.

To investigate the prevalence of the point mutations described above, we examined three additional unrelated patients who had no family history of consanguinity. As shown above, one patient $(\mathrm{Pc})$ was a possible compound heterozygote with only one allele containing the same mutation as patient 2 . The other two patients, however, had none of the mutations identified thus far.

We also constructed the DNA haplotypes for the five patients using a combination of the alleles which were determined by the three RFLPs $(23,24)$ (Table III). Only three haplotypes were found among the patients, because haplotype $C$ (H2 B1 P2) was common to the three affected chromosomes with respective mutant alleles. In 50 unrelated Japanese controls, allelic frequencies were $\mathrm{H} 1=0.28, \mathrm{H} 2=0.72 ; \mathrm{B} 1=0.85$, $\mathrm{B} 2=0.15 ; \mathrm{P} 1=0.22, \mathrm{P} 2=0.78$, respectively. Therefore, haplotype $\mathrm{C}$ is quite likely to be the most prevailing haplotype in the Japanese population.

The LPL enzyme mass in the postheparin plasma of the patients was measured by an ELISA using polyclonal antibodies raised against human LPL (Table IV). Virtually no LPL enzyme mass was detected in plasma from patients 1 and 2 , suggesting that the genetic defects in these two patients are null-allelic mutations. Regarding the other three patients, variously decreased but significant levels of LPL mass were found in their postheparin plasma. In contrast, the enzyme mass in the preheparin plasma from the three patients was uniformly at undetectable levels (data not shown).

To examine the functional significance of the two missense mutations, expression plasmids coding for the normal LPL (pCMV-LPL) as well as the $\mathrm{Glu}^{204}$ and $\mathrm{His}^{243}$ mutants (pLPL$\mathrm{Glu}^{204}$ and pLPL-His ${ }^{243}$ ) were transfected into COS-1 cells, and both the media and the cell homogenates were assayed for LPL mass and activity. Media harvested from cells transfected with the pLPL-Glu ${ }^{204}$ and pLPL-His ${ }^{243}$ mutant plasmids contained decreased levels of LPL mass (26 and $24 \%$ of the level in normal control, respectively), whereas such decreases in the level of LPL mass were less significant in the cell homogenates (73 and $61 \%$ of normal control, respectively) (Fig. $5 \mathrm{~A}$ ). Neither of the mutant proteins showed detectable enzymatic activity both in the media and in the cells (Fig. $5 \mathrm{~B}$ ). These data demonstrated that the Asp ${ }^{204} \rightarrow$ Glu and the $\mathrm{Arg}^{243} \rightarrow$ His mutations both result in the production of LPL molecules which are catalytically defective and are less efficiently secreted from the expressing cells.

\section{Discussion}

In this paper, we described five distinct point mutations responsible for LPL deficiency and developed diagnostic tests for the rapid detection of each mutation. We also measured the LPL enzyme mass and performed transient expression of the mutant LPL cDNAs in mammalian cells. The results provide a new insight into the molecular basis of LPL deficiency as well as into the structure-function relationship of this important enzyme.

At the first nucleotide of intron 2, patient 1 has a G-to-A substitution that converts the invariant dinucleotides GT into AT in the donor splice site of eukaryotes (32). It is well established that the GT dinucleotides are essential and obligatory for normal splicing of pre-mRNA as they are involved in the correct splice site selection (33). In fact, we have recently demonstrated aberrant splicing in this patient, which resulted in decreased levels of LPL mRNA (Gotoda, T., et al., unpublished results).

LPL is a unique enzyme with multiple functional domains which are postulated to be confined to specific exons. Many investigators assign the asparagine-linked glycosylation site required for the expression of enzyme activity to exon 2 , the

Table III. DNA Haplotypes at the LPL Gene Locus in the Five Patients

\begin{tabular}{|c|c|c|c|c|c|}
\hline Patient No. & Mutation & Haplotype & Hind III & Bam HI & Pvu II \\
\hline Patient 1 & $\mathrm{GT} \rightarrow \mathrm{AT}$ & Haplotype A & $\mathrm{H} 2^{*}$ & B1 & P1 \\
\hline Patient 2 & Tyr ${ }^{61} \rightarrow$ Stop & Haplotype B & H1 & B1 & P1 \\
\hline Patient 3 & $\operatorname{Trp}^{382} \rightarrow$ Stop & Haplotype C & $\mathrm{H} 2$ & B1 & P2 \\
\hline Patient 4 & $\mathrm{Asp}^{204} \rightarrow \mathrm{Glu}$ & Haplotype C & $\mathrm{H} 2$ & B1 & $\mathbf{P} 2$ \\
\hline Patient 5 & $\operatorname{Arg}^{243} \rightarrow$ His & Haplotype C & $\mathbf{H} 2$ & B1 & $\mathbf{P} 2$ \\
\hline
\end{tabular}

${ }^{*} \mathrm{H} 1$ indicates the allele characterized by the band of $17.5 \mathrm{~kb}$. H2, $8.7 \mathrm{~kb}$; B1, $33 \mathrm{~kb}$; B2, $19 \mathrm{~kb}$; P1, 7.9 kb; P2, 5.1 and $2.8 \mathrm{~kb}$, respectively. 
Table IV. LPL Enzyme Mass in the Postheparin Plasma of the Five Patients

\begin{tabular}{lccl}
\hline Patient No. & Mutation & LPL enzyme mass* & \multicolumn{1}{c}{ Protein class $^{*}$} \\
\hline & & $n g / m l$ & \\
Patient 1 & $\mathrm{GT} \rightarrow$ AT & 2 & Class I defect \\
Patient 2 & $\mathrm{Tyr}^{61} \rightarrow$ Stop & 0 & Class I defect \\
Patient 3 & $\mathrm{Trp}^{382} \rightarrow$ Stop & 22 & Class II or III defect \\
Patient 4 & $\mathrm{Asp}^{204} \rightarrow$ Glu & 118 & Class II defect \\
Patient 5 & Arg $^{243} \rightarrow$ His & 84 & Class II defect
\end{tabular}

* Controls $(n=6): 410 \pm 96$ (mean \pm SD). ${ }^{\ddagger}$ Classification of protein defects according to Auwerx et al. (7).

catalytic serine and the lipid binding domain to exon 4 , the highly conserved central domain to exon 5 , and the heparin binding site to exon $6(8,10,12,34)$. The introduction of a premature stop codon into exon 3 in patient 2 can thus be easily predicted as exerting the lethal effect on translation. Actually, LPL immunoreactive mass was completely absent in the postheparin plasma of patient 2 , as well as in that of patient 1 (Table IV). Thus, these patients exhibit the class I protein defect described by Auwerx et al. (7) which is characterized by null-phenotypic expression.

More informative is the nonsense mutation in patient 3 , which occurs in the middle of exon 8 and would terminate translation after synthesizing $>85 \%$ of the normal LPL, including all functional domains noted above. Earlier studies demonstrated that chymotryptic digestion of bovine LPL eliminates the carboxy-terminal portion and causes a loss of activity, not with soluble substrates but with insoluble substrates (35). Recent peptide sequencing analysis of bovine LPL located the chymotrypsin nick immediately after $\mathrm{Phe}^{390}$ (the equivalent of $\mathrm{Phe}^{\mathbf{3 8 8}}$ in human LPL) and suggested the succeeding hydrophobic region for another interfacial lipid binding domain (36).
Our finding of a nonsense mutation at $\operatorname{Tr}^{382}$ in an LPL-deficient patient supports the notion that the carboxy-terminus of LPL is highly important, probably because it is involved in lipid binding. Decreased levels of mRNA, as are often observed in nonsense mutations (37), may also contribute to the LPL deficiency in patients 2 and 3.

Of the 448 amino acid residues consisting of human LPL, only 30 amino acids are completely conserved both among species and among the lipase gene family which is composed of LPL, hepatic lipase, pancreatic lipase, and yolk protein (11). The two missense mutations found in patients 4 and 5 both occurred in one of such highly conserved amino acid residues, suggesting an essential role of these amino acids in normal lipolytic function.

The Asp $^{204} \rightarrow$ Glu substitution in exon 5 of patient 4 is indeed a subtle change with a single methylene addition, but conformation analysis by the Chou and Fasman algorithm (38) predicted that the amino acid change would disrupt a $\beta$-sheet configuration. Furthermore, the base change is not a common polymorphism, because the same base change was not observed in the other 50 alleles examined. Exon 5 encodes the central homologous region which has highly conserved sequences (10). Recently, three missense mutations were identified in exon 5 , and the validity of each mutation was confirmed by in vitro expression studies. The Gly ${ }^{188} \rightarrow$ Glu (15) and $\mathrm{Ala}^{176} \rightarrow \mathrm{Thr}(16)$ substitutions both resulted in the synthesis of a catalytically inactive enzyme with a decreased affinity for heparin, and the II $\mathrm{I}^{194} \rightarrow$ Thr change (19) produced an inactive enzyme with normal heparin affinity. These mutant proteins were present abundantly in the postheparin plasma and were normally expressed in the culture medium of the transfected cells. By contrast, COS-1 cells transfected with the mutant plasmid pLPL-Glu ${ }^{204}$ produced a unique inactive enzyme, which was decreased in amount and was less efficiently secreted from the cells (Fig. 5). In addition, the significant increment in the LPL mass in the patient's postheparin plasma, which is charac-
A

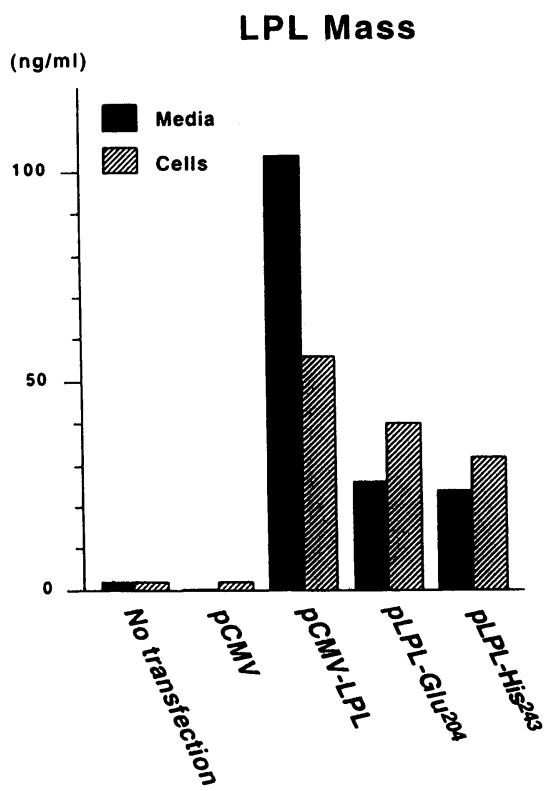

B

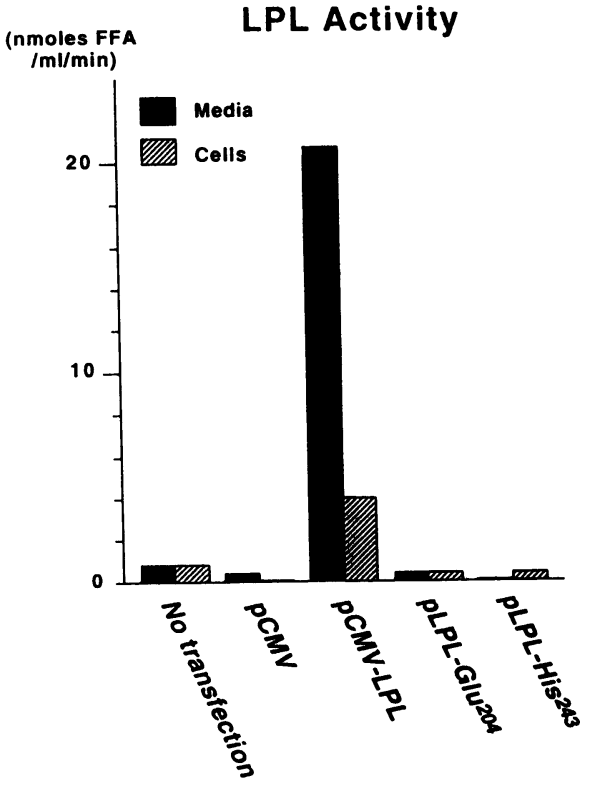

Figure 5. LPL expression in COS-1 cells transfected with the normal and mutant expression vectors. COS cells were transfected with $\mathrm{Rc} / \mathrm{CMV}$ vector without insert (denoted pCMV), or with pCMV-LPL carrying the normal LPL CDNA, or with pLPL-Glu ${ }^{204}$ carrying the Asp ${ }^{204} \rightarrow$ Glu mutant cDNA, or with pLPL$\mathrm{His}^{243}$ carrying the $\mathrm{Arg}^{243} \rightarrow$ His mutant cDNA. $(A)$ LPL mass is in nanograms per milliliter. $(B)$ LPL activity is expressed as nanomoles of free fatty acids per milliliter per minute. LPL mass and activity were measured both in the culture medium (solid bars) and in cell homogenates (hatched bars). 
teristic of the class II defect (7), indicated normal heparin binding of the mutant LPL (Table IV). These effects of the mutation at $\mathrm{Asp}^{204}$ have more similarities to those of the mutations at $\mathrm{Arg}^{243}$ in exon 6 (Fig. 5) and at Gly ${ }^{142}$ in exon 4 (20) rather than to those of the other mutations in exon 5 . Therefore, although the dispersion of the mutations in exon $5\left(\mathrm{Ala}^{176}, \mathrm{Gly}^{188}, \mathrm{II}^{194}\right.$, $\mathrm{Asp}^{204}$ ) implies the presence of an extensive region necessary for normal LPL function, the amino acid substitutions that occur within the same region can cause different effects on the enzyme. It is also noteworthy that both the rather conservative amino acid changes at $\mathrm{Asp}^{204}$ as well as at $\operatorname{Ser}^{244}$ (18) can abolish LPL function completely. The fact should indicate the extreme intolerance of the LPL molecule to the alterations caused by an amino acid substitution.

The G-to-A transition in exon 6 of patient 5 , which was similarly proved not to be a common polymorphism, also occurs in the highly conserved $\mathrm{Arg}^{243}$. Interestingly, the same base substitution was recently also found in a Caucasian patient (19). Recently, X-ray crystallographic analysis of human pancreatic lipase revealed that the lipolytic site of the enzyme is formed by a triad structure which is composed of $\operatorname{Ser}^{152}, \mathrm{Asp}^{176}$, and $\mathrm{His}^{263}$ (equivalent to $\mathrm{Ser}^{132}$, $\mathrm{Asp}^{156}$, and $\mathrm{His}^{241}$ in human LPL, respectively) (39). Because the $\mathrm{Arg}^{243} \rightarrow$ His substitution occurs close to the $\mathrm{His}^{241}$ which is essential for the formation of the catalytic triad, the change is likely to cause the disruption of the enzyme catalytic site. Expression studies demonstrated that the $\operatorname{Arg}^{243} \rightarrow$ His substitution not only abolishes enzyme activity but also decreases enzyme secretion.

The heterogeneity of familial LPL deficiency has been suggested by biochemical $(5,6)$ and immunological $(7)$ analyses. In this study, we found heterogeneity of this disease also at the molecular level. The diversity of the gene mutation was further supported by the examinations of the three additional patients, which suggested the existence of other undefined mutations even within the relatively homogeneous Japanese population. Taking into account such a variety of gene mutations, it is expected that different mutations can exist on the chromosomes with an identical haplotype. Actually as shown in Table III, haplotype $\mathrm{C}$ was found in the three affected chromosomes with respective distinct mutations. Furthermore, haplotype $C$ was recently also found in the insertional mutation, and haplotype $A$ in the missense mutation at $\operatorname{Gly}^{188}(40)$. Without more extensive RFLP analysis, DNA haplotyping can only provide limited genetical information regarding LPL deficiency. Identification of a series of naturally occurring mutations, therefore, will be the first step to establish a practical diagnostic system of familial LPL deficiency at the DNA level.

\section{Acknowledgments}

We are indebted to Drs. Shunichi Koga, Hidenori Yamawaki, Shuichi Kanazashi, Yasuhiko Iwamoto, Ritsuko Honda, and Ryuzo Abe for providing blood samples of the patients; to Drs. Mototaka Senda, Kazuhiro Oka, Shuichi Nozaki, Yuji Matsuzawa, Jun Tashiro, Junji Kobayashi, Kohji Shirai, and Yasushi Saito for helpful suggestions; and to Dr. Akiyo Matsumoto and Dr. Hiroshige Itakura for generous support.

\section{References}

1. Garfinkel, A. S., and M. C. Schotz. 1987. Lipoprotein lipase. In Plasma Lipoproteins. A. M. Gotto, Jr., editor. Elsevier Science Publishers, New York. 335-357.
2. Bürger, M., and O. Grütz. 1932. Über hepatosplenomegale lipoidose mit xanthomatosen veränderungen in haut und schleimhaut. Arch. Dermatol. Syph. 166:542-575.

3. Havel, R. J., and R. S. Gordon, Jr. 1960. Idiopathic hyperlipemia: metabolic studies in an affected family. J. Clin. Invest. 39:1777-1790.

4. Brunzell, J. D. 1989. Familial lipoprotein lipase deficiency and other causes of the chylomicronemia syndrome. In The Metabolic Basis of Inherited Disease. 6th ed. C. R. Scriver, A. L. Beaudet, W. S. Sly, and D. Valle, editors. McGraw-Hill Book Co., New York. 1165-1180.

5. Schreibman, P. H., D. L. Arons, C. D. Saudek, and R. A. Arky. 1973. Abnormal lipoprotein lipase in familial exogenous hypertriglyceridemia. J. Clin. Invest. 52:2075-2082.

6. Brunzell, J. D., A. Chait, E. A. Nikkilä, C. Ehnholm, J. K. Huttunen, and G. Steiner. 1980. Heterogeneity of primary lipoprotein lipase deficiency. Metabolism (Clin. \& Exp.). 29:624-629.

7. Auwerx, J. H., S. P. Babirak, W. Y. Fujimoto, P.-H. Iverius, and J. D. Brunzell. 1989. Defective enzyme protein in lipoprotein lipase deficiency. Eur. J. Clin. Invest. 19:433-437.

8. Wion, K. L., T. G. Kirchgessner, A. J. Lusis, M. C. Schotz, and R. M. Lawn. 1987. Human lipoprotein lipase complementary DNA sequence. Science (Wash. DC). 235:1638-1641.

9. Senda, M., K. Oka, W. V. Brown, P. K. Qasba, and Y. Furuichi. 1987. Molecular cloning and sequence of a cDNA coding for bovine lipoprotein lipase. Proc. Natl. Acad. Sci. USA. 84:4369-4373.

10. Deeb, S. S., and R. Peng. 1989. Structure of the human lipoprotein lipase gene. Biochemistry. 28:4131-4135.

11. Kirchgessner, T. G., J.-C. Chuat, C. Heinzmann, J. Etienne, S. Guilhot, K. Svenson, D. Ameis, C. Pilon, L. d'Auriol, A. Andalibi, M. C. Schotz, F. Galibert, and A. J. Lusis. 1989. Organization of the human lipoprotein lipase gene and evolution of the lipase gene family. Proc. Natl. Acad. Sci. USA 86:9647-9651.

12. Oka, K., G. T. Tkalcevic, T. Nakano, H. Tucker, K. I. Oka, and W. V. Brown. 1990. Structure and polymorphic map of human lipoprotein lipase gene. Biochim. Biophys. Acta. 1049:21-26.

13. Langlois, S., S. Deeb, J. D. Brunzell, J. J. Kastelein, and M. R. Hayden. 1989. A major insertion accounts for a significant proportion of mutations underlying human lipoprotein lipase deficiency. Proc. Natl. Acad. Sci. USA. 86:948952.

14. Devlin, R. H., S. Deeb, J. D. Brunzell, and M. R. Hayden. 1990. Partial gene duplication involving exon-Alu interchange results in lipoprotein lipase deficiency. Am. J. Hum. Genet. 46:112-119.

15. Emi, M., D. E. Wilson, P.-H. Iverius, L. Wu, A. Hata, R. Hegele, R. R. Williams, and J.-M. Lalouel. 1990. Missense mutation (Gly $\rightarrow$ Glu $^{188}$ ) of human lipoprotein lipase imparting functional deficiency. J. Biol. Chem. 265:59105916.

16. Beg, O. U., M. S. Meng, S. I. Skarlatos, L. Previato, J. D. Brunzell, H. B.

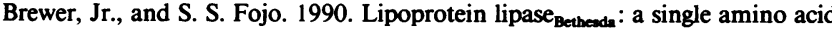
substitution (Ala-176 $\rightarrow$ Thr) leads to abnormal heparin binding and loss of enzymic activity. Proc. Natl. Acad. Sci. USA 87:3474-3478.

17. Emi, M., A. Hata, M. Robertson, P.-H. Iverius, R. Hegele, and J.-M. Lalouel. 1990. Lipoprotein lipase deficiency resulting from a nonsense mutation in exon 3 of the lipoprotein lipase gene. Am. J. Hum. Genet. 47:107-111.

18. Hata, A., M. Emi, G. Luc, A. Basdevant, P. Gambert, P.-H. Iverius, and J.-M. Lalouel. 1990. Compound heterozygote for lipoprotein lipase deficiency: Ser $\rightarrow$ Thr $^{244}$ and transition in $3^{\prime}$ splice site of intron $2(A G \rightarrow$ AA) in the lipoprotein lipase gene. Am. J. Hum. Genet. 47:721-726.

19. Dichek, H. L., S. S. Fojo, O. U. Beg, S. I. Skarlatos, J. D. Brunzell, G. B. Cutler, Jr., and H. B. Brewer, Jr. 1991. Identification of two separate allelic mutations in the lipoprotein lipase gene of a patient with the familial hyperchylomicronemia syndrome. J. Biol. Chem. 266:473-477.

20. Ameis, D., J. Kobayashi, R. C. Davis, O. Ben-Zeev, M. J. Malloy, J. P. Kane, G. Lee, H. Wong, R. J. Havel, and M. C. Schotz. 1991. Familial chylomicronemia (type I hyperlipoproteinemia) due to a single missense mutation in the lipoprotein lipase gene. J. Clin. Invest. 87:1165-1170.

21. Gotoda, T., M. Senda, T. Murase, N. Yamada, F. Takaku, and Y. Furuichi. 1989. Gene polymorphism identified by Pvu II in familial lipoprotein lipase deficiency. Biochem. Biophys. Res. Commun. 164:1391-1396.

22. Gotoda, T., M. Senda, T. Gamou, Y. Furuichi, and K. Oka. 1989. Nucleotide sequence of human cDNA coding for a lipoprotein lipase (LPL) cloned from placental cDNA library. Nucleic Acids Res. 17:2351.

23. Heinzmann, C., J. Ladias, S. Antonarakis, T. Kirchgessner, M. Schotz, and A. J. Lusis. 1987. RFLP for the human lipoprotein lipase (LPL) gene: Hind III. Nucleic Acids Res. 15:6763.

24. Fisher, K. L., G. A. FitzGerald, and R. M. Lawn. 1987. Two polymorphisms in the human lipoprotein lipase (LPL) gene. Nucleic Acids Res. 15:7657.

25. Saiki, R. K., D. H. Gelfand, S. Stoffel, S. J. Scharf, R. Higuchi, G. T. Horn, K. B. Mullis, and H. A. Erlich. 1988. Primer-directed enzymatic amplification of DNA with a thermostable DNA polymerase. Science (Wash. DC). 239:487-491.

26. Gyllensten, U. B., and H. A. Erlich. 1988. Generation of single-stranded 
DNA by the polymerase chain reaction and its application to direct sequencing of the HLA-DQA locus. Proc. Natl. Acad. Sci. USA. 85:7652-7656.

27. Sanger, F., S. Nicklen, and A. R. Coulson. 1977. DNA sequencing with chain-terminating inhibitors. Proc. Natl. Acad. Sci. USA. 74:5463-5467.

28. Higuchi, R. 1990. Recombinant PCR. In PCR Protocols: A Guide to Methods and Applications. M. A. Innis, D. H. Gelfand, J. J. Sninsky, and T. J. White, editors. Academic Press, Inc., New York. 177-183.

29. Murase, T., N. Yamada, N. Ohsawa, K. Kosaka, S. Morita, and S. Yoshida. 1980. Decline of postheparin plasma lipoprotein lipase in acromegalic patients. Metabolism (Clin. \& Exp.). 29:666-672.

30. Breckenridge, W. C., J. A. Little, G. Steiner, A. Chow, and M. Poapst. 1978. Hypertriglyceridemia associated with deficiency of apolipoprotein C-II. $N$. Engl. J. Med. 298:1265-1273.

31. Babirak, S. P., P.-H. Iverius, W. Y. Fujimoto, and J. D. Brunzell. 1989. Detection and characterization of the heterozygote state for lipoprotein lipase deficiency. Arteriosclerosis. 9:326-334.

32. Mount, S. M. 1982. A catalogue of splice junction sequences. Nucleic Acids Res. 10:459-472.

33. Green, M. R. 1986. Pre-mRNA splicing. Annu. Rev. Genet. 20:671-708.

34. Semenkovich, C. F., C.-C. Luo, M. K. Nakanishi, S.-H. Chen, L. C. Smith, and L. Chan. 1990. In vitro expression and site-specific mutagenesis of the cloned human lipoprotein lipase gene. J. Biol. Chem. 265:5429-5433.

35. Bengtsson-Olivecrona, G., T. Olivecrona, and H. Jörnvall. 1986. Lipoprotein lipases from cow, guinea-pig and man, structural characterization and identification of protease-sensitive internal regions. Eur. J. Biochem. 161:281-288.

36. Yang, C.-Y., Z.-W. Gu, H.-X. Yang, M. F. Rohde, A. M. Gotto, Jr., and H. J. Pownall. 1989. Structure of bovine milk lipoprotein lipase. J. Biol. Chem. 264:16822-16827.

37. Atweh, G. F., H. E. Brickner, X.-X. Zhu, H. H. Kazazian, Jr., and B. G. Forget. 1988. New amber mutation in a $\beta$-thalassemic gene with nonmeasurable levels of mutant messenger RNA in vivo. J. Clin. Invest. 82:557-561.

38. Chou, P. Y., and G. D. Fasman. 1978. Prediction of the secondary structure of proteins from their amino acid sequence. Adv. Enzymol. 42:45-148.

39. Winkler, F. K., A. D'Arcy, and W. Hunziker. 1990. Structure of human pancreatic lipase. Nature (Lond.). 343:771-774.

40. Monsalve, M. V., H. Henderson, G. Roederer, P. Julien, S. Deeb, J. J. P. Kastelein, L. Peritz, R. Devlin, T. Bruin, M. R. V. Murthy, C. Cagne, J. Davignon, P. J. Lupien, J. D. Brunzell, and M. R. Hayden. 1990. A missense mutation at codon 188 of the human lipoprotein lipase gene is a frequent cause of lipoprotein lipase deficiency in persons of different ancestries. J. Clin. Invest. 86:728734. 